\title{
Deveoping An Ideal Leadership Succession Model For The Malaysian Public Service
}

\author{
Mohd Hafizzuddin MD Damiri ${ }^{1}$
}

\section{Disclaimer}

The opinions in this paper is purely academic and for research purposes on the topic of leadership and succession planning. The author's opinion is based on materials and resources, gathered and analyzed for the purpose of writing this paper, and does not reflect any official position or policy by any related departments or the Government of Malaysia.

\begin{abstract}
Leadership succession in the Malaysian Public Service's higher management has been seen as one of the most important task for Jabatan Perkhidmatan Awam (JPA). This department acts as the centralized administrator for human resources for the whole of the Malaysian Public Service - excluding the Royal Malaysian Police (PDRM) and the Malaysian Armed Forces (ATM) - and determines the career path for all schemes under their purview, which includes officials of the Perkhidmatan Tadbir dan Diplomatik (PTD), the Pegawai Perkhidmatan Latihan dan Vokasional (PPLV) and the Pegawai Perkhidmatan Psikologi (PPPsi). This paper will review the hypothetical leadership succession strategies and any developed models in the Malaysian public sector, through various available literatures, guidelines and processes.
\end{abstract}

Keywords: leadership, succession planning, succession model, public sector, Malaysia.

\section{Introduction}

The process in selecting "the next in line" of succession, especially to head a Ministry at the higher management level is still cloudy. Though JPA can claim that succession is from the "second in command" of the Ministry, the current situation does not permit so to happen. The succession has and always been seen as "preferential"; by the higher mana- gement it is known as "the point system", where the Minister will "point" to a successor favorable to him.

According to Hirsh (2000), succession planning is "a process by which one or more successors are identified for key posts and career moves, where development activities are planned for these successors. Successors may be fairly ready to do the job or seen as having longer-term potential". Rothwell (2005) in his

\footnotetext{
${ }^{1}$ Service Division Public Service Department, Malaysia. Email : hafizz.damiri@jpa.gov.my
} 
book "Effective Succession Planning" defined the process of succession planning is the "effort designed to ensure the continued effective performance of an organization or work groups by making provision for the develoment and replacement of key people over time".

Acknowledging that the higher management posts in the Malaysian Public Service is aging - with no strategic possibilities of suitable or available replacements - the department has since taken initiatives by benchmarking with other countries, such as Australia, New Zealand and the United Kingdom, for them to find the best possible solution to mitigate such instances. To date, none has been successful, as political pressure and loyalty demand by the political masters has disabled the process of leadership succession in the higher management of the public sector.

Therefore this paper can be seen as vital to highlight the need of developing a suitable and more comprehensive model in leadership succession, not only for the higher management in the Malaysian Public Service, but additionally in a holistic approach throughout the service for an individual in the system.

\section{Methodology}

The methodology used in this paper is qualitative in nature, which enables for a more explorative and narrow spectrum approach on how the current leadership succession model is used in the Malaysian public service. By examining the process used in determining how a successor is chosen for a specific position, such method has enabled this study to further analyze and identify the impediments towards effective leadership succession in the Malaysian Public Service, giving focus to the requirements needed for an individual to be recommended in the succession plan itself. Finally, this method will provide the opportunity to evaluate the effectiveness of the current leadership succession model through comparing with other known established models, benchmarked by the Malaysian public service.

In addition, this methodology will also enable a study to be established at a more theoretical reference from existing management or leadership succession theorists, and propose an improvement towards the current implemented model by the Malaysian public service.

\section{Significance of the Paper}

This study on leadership succession can be a learning paradigm in the Malaysian public service to enhance and further improve their current leadership succession model. This research also aims to enrich the design in career path planning, as well as personal skills needed by a leader, which could further motivate personal determination and improve the image of the Malaysian public service in the long term period.

In addition, this study will be beneficial in improving the knowledge and understanding of the Malaysian public service towards a systematic process in leadership succession, through a model that can be revised according to future requirements. This will be a wealth of knowledge contribution, especially to the Malaysian public service personnel to better understand the process of leadership succession and make further research in this area in the future.

\section{The Malaysian Public Sector Succession Model}

The continued survival of an organization depends on having the right people, at the right place and at the right time, where a deliberate and systematic should be in place by the organization to ensure continuity in the key positions and encourage individual advancement. Due to the recent change of government after the $14^{\text {th }}$ General Elections in May 2018, many ministries and government agencies in Malaysia has been merged and their personnel downsized, which reduced many positions in the middle management ranks.

For JPA to create an effective leadership succession model, it should apply tailored techniques in identifying specific people to fill future openings in key positions througout the organization, having specific procedures to 
ensure the identification development process and long-term retention of talented and knowledgeable individuals within the Malaysian public service.

Currently, there is no specific model that the Malaysian public service is following, especially in designating a successor to spearhead a Ministry, let alone any Government Agency in Malaysia. The "one-size-fits-all" approach by JPA which based the recommendations from political preference and "off-hand" decision makers has made the Malaysian public service a critical point of attack, especially from the public's perception.

One of the biggest challenges in the public sector is sustaining innovation and programs in the face of changing administrations, politics and priorities. Despite various efforts by JPA to implement a "topdown", "bottom-up" and 360 approaches in selecting the best candidate to spearhead a Government Agency, due to pressure from political masters have hindered the process in selecting the "best candidate for the best post", thus rendering the statement "putting the right person, at the right place" by many management and leadership theorists useless.

Though introducing the Blue Ocean Strategy (BOS) can be seen as the latest trend in the management market, it is not suitable for the Malaysian Public Service to embark in such strategy, as the Malaysian Public Service is a "service-oriented" and not "market profitoriented" entity. Instead, the Malaysian Public Service should establish its own unique model, especially in appointing the suitable candidate for leadership succession, based on criterias that is often referred by established leadership theorists and global successful private firms.

\section{Literature Review}

The concept of leadership succession has long been a subject of study in the private sector, but not in the public sector. Out of 130 studies of leadership, management or succession planning conducted between 1980 and 1993, only five involved the public sector (Kesner and Sebora, 1994). Nonetheless, succession plan- ning is increasingly discussed in the public sector and the dangers of not having adequate succession plans and mechanisms in place are becoming more obvious (Cipolla, 1993).

Succession planning is the means by which an organization prepares for and replaces leaders, managers, executives and other key employees who leave their positions. It is crucial and important to the organization for its continuity and future success (Gilmore, 1988). This process includes how the organization identifies and recruits successors, how it manages transitions from one personnel to another and how it develops successors. Planning a succession can also involve identifying potential employees and including them in special training and development for future leadership roles. This practice of succession planning is key to sustaining an organization's initiatives and performance, to ensure it meets its goals in the future.

Leadership succession planning in the private sector has been more formalized than that of the public sector. The lack of focus on succession planning in the public sector has had severed impacts, and according to Barkdoll and Mocniak (1993), "the loss of experienced executives without adequate replacements can have a substantial, immediate negative effect on an organization".

As such, the Malaysian public service had not been sufficiently preparing their personnel to take over the responsibilities and positions of its leadership, and the majority of those in the senior and top management were rapidly approaching the age of 55 years, the age at which most Malaysian public servants are contratually required to retire (other options of retirement include choosing either 56,58 or 60 years of age), while the younger personnel in the junior or middle management had not been sufficiently groomed for succession.

The sign of restlessness could be observed by those who are still serving the the public service, and that this overall situation did not fare well for the public service in terms of strategic leadership continuity. Leadership succession is the proactive identification and 
development of subordinates for future management or leadership positions at all levels of the Malaysian Public Service and can be contrasted to leadership replacement which is the reactive initiation of efforts to find a replacement for a promoted or retiring personnel.

In addition, the labor market conditions over the last several years have combined with demographic and social trends to increase the competition for talent between the public and private sectors. This has led many public agencies to reexamine their approach to managing talent and to consider adopting strategies similar to those of the private sector for attracting and retaining it. While some of these efforts have succeeded, challenges specific to the public sector have impede implementing these programs difficult.

A recent literature search shows that while articles on succession in the private sector continues to proliferate, there continues to be a lack of strong public sector models. This has been the case for some time. Kesner and Sebora (1994) reviewed the literature on succession planning that had been published between 1960 and 1993 and drew several conclusions. First, while there was a sharp increase in the literature beginning in 1980, a lack of successful, proven strategies remained. Second, ambiguity about the results of many successions and succession planning methods still existed. Finally, further exploration was necessary to determine the factors and strategies in successful transitions.

While Kesner and Sebora noted that most of the studies had focused on the origin of the successor and the consequences of the succession, they concluded that this period was only the beginning of a comprehensive study of succession planning (Kesner and Sebora, 1994). Schall (1997) echoed their lament about the lack of literature, particularly in the public sector. She noted that serious study of succession planning in the public sector only began in 1992. Since then, most literature had focused on the transition of the chief executive officer, where Schall noted an overall lack of focus on successful transition at the agency level and suggested this was "an area for future research"
(Schall, 1997).

In the course of this study, the researcher noticed that Kesner and Sebora found only three studies of transition in the public sector, and all of it involved universities. Santora and Sarros (1995) also found little conclusive data about transition in the public sector, and noted that much research was needed in this area.

From these authors' perspective, literature in the public sector leadership succession planning was scant because many leaders in these sector believed that no one else was capable of leading the organization and because many public sector leaders had long tenures (Santora and Sarros, 1995). Consequently, succession issues have only recently begun to come to the fore in this sector. Working with organizations, the authors above have seen the concern about pending retirements among higher public management leaders, and that had triggered an interest in public sector leadership succession planning.

Effective leadership succession planning requires the systematic integration of human resource development, strategy and governance. From the human resource factor, leadership succession entails specialized coordination of selection, performance appraisal, and training and development. The outcomes of leadership succession decisions have long lasting effects on the direction and achievement of the organization's strategies. These strategic decisions are made by higher management level, who may be grappling with conflict between their personal desire to remain in the job and their professional obligation to facilitate succession.

Leadership succession constitutes one of the most important task of an organization. The key reasons organizations need to engage in leadership succession can be divided into three imperatives: maintaining operational effectiveness, managing strategic direction, and influencing stakeholder perceptions. Leadership succession programs assist in averting the negative operational impact of a leadership vacuum. Unplanned succession events, such as resignation or sudden death, can result in the loss of a critical dimension that makes the organization competitive (Burdett, 1993). 


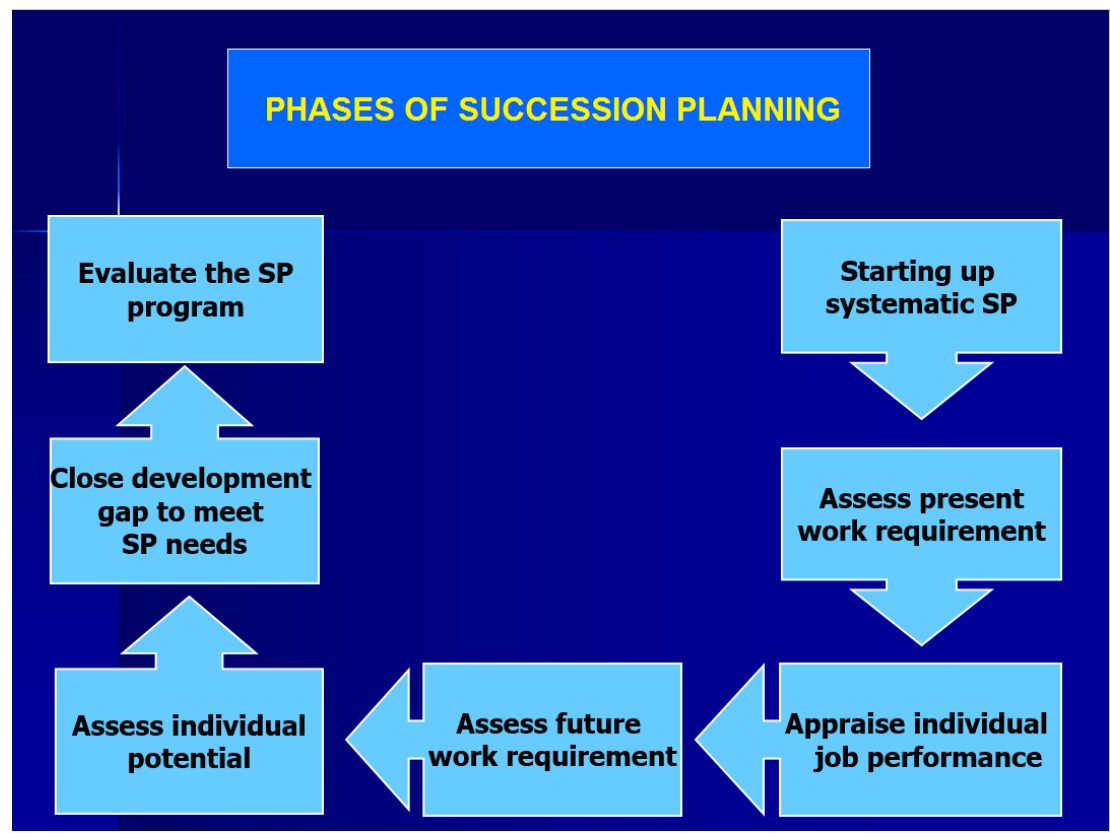

(Fig. 1: Phases of Succession Planning Program, Pekeliling Perkhidmatan Bilangan 3, Tahun 2006 - trans. Service Circular Number 3, Year 2006)

According to the Pekeliling Perkhidmatan Bilangan 3 Tahun 2006 - a guide to create a search committee and how to implement the process of a succession plan specificies its focus towards a group of potential employees to be polished in their talents and abilities to achieve the vision of an organization. The so-called guide stated that this process will be beneficial to potential individuals in terms of their career development, which means the succession plan provides a "win-win" situation to both parties and was seen as a match between an organization's futuristic needs and employee aspirations. To this day, the success rate of the guide has not been proven, and as this study found out, there are reasons to why the guide cannot be applicable, due to current political scenario and favoritism.

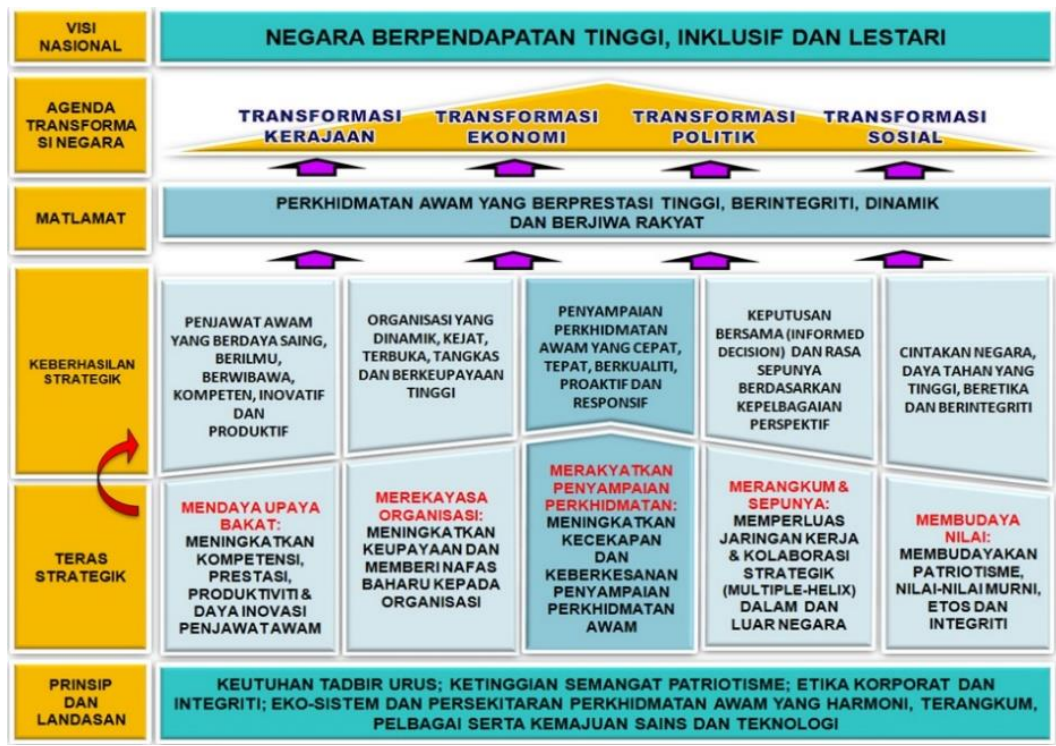

(Fig. 2: Kerangka Transformasi Perkhidmatan Awam - trans. Public Service Transformation Framework) 
Based on the Strategic Thrusts under the Kerangka Transformasi Perkhidmatan Awam, in creating competent, high-performance, productive and innovative civil servants, the Service Division of JPA is responsible for developing the competence of all levels of its personnel's competence in the Malaysian Public Service.

Competency development is an essential element in ensuring that these personnel have high moral values and personality, as well as the strengthening of knowledge that can be applied with working experience and essential tasks. In addition, the element of interest in a field that is not an essential task should also be emphasized, in further ensuring competency development programs can be formulated and implemented successfully.

Currently, the Human Capital Development (HCD) program implemented by the Service Division of JPA is linked to individual career planning and progress, where at each grade of service, training will be applied as required by JPA. However, the adjustment of the HDP program cannot be justified with the competence or interest of the personnel, thus causing the personnel to be unwilling, or the change in responsibilities suddenly resulting in the personnel unable to perform the task entrusted to the optimum.

The same can be said on leadership succession. The department, through its training arm, the Institut Tadbiran Awam Negara or INTAN conducted several "leadership" programs, mandatory for PTD officials, as well as other officials from various schemes under the Malaysian Public Service. The participants of this program are senior officials who are to be confirmed in the Jawatan Utama Sektor Awam (JUSA) or equivalent in the Royal Malaysian Police (PDRM) or Malaysian Armed Forces (ATM).

This program conducted only to the senior officials has the aim at developing and assessing their knowledge, skill and leadership competency, and gives focus particular to affective, psychomotor and cognitive learning domains. Accordingly, the program is expected to have the following outcome, that reflects and impacts its participants, among others: (i) capable of engaging in an active and supportive community; (ii) capable to demonstrate leadership capabilities; (iii) able to exhibit knowledge and skills through the utilization of various management and strategic planning tools; (iv) create awareness and understanding of areas within or beyond the public service environment through targeted reading materials; and (v) enable to demonstrate exemplary character and positive values.

Nonetheless, the program conducted by INTAN only focus on senior and top management personnel and not from the junior or middle management personnel process. It should be done according to the process conducted by the private sector, where once a junior level personnel has been identified with the traits conforming to leadership material, the personnel will be further developed and trained in the pipelines as one of the candidate suitable in the leadership succession plan of the organization. And most of those attended the course did not even exhibit the traits of a leader, let alone having the charisma of a leader.

While the course of this study is to attempt in simplifying the process by addressing the research question, the researcher has also taken into consideration several aspects that may influence judgement in not applying the leadership succession process. This would include why the public sector higher management does not see the importance of leadership succession, what problems inhibits the success of a leadership succession plan, and what are the elements that is seen fit in the public sector higher management succession model.

For the public sector, the program that was developed was more towards developing and assessing the personnel's knowledge and skill, without having a specific leadership competency outline. Even though INTAN and JPA had some skeleton ideas on the approach, but in contrast, the program only concentrated on (i) developing and assess transformative leadership; (ii) strengthening critical and 
innovative analysis from different dimensions and perspectives; (iii) enhancing strategic visioning and scenario planning; (iv) improving on networking, collaboration and teamwork; and (v) developing awareness and understanding the areas within the public service domain, in a theoretical perspective. Therefore, it can be presumed that despite existing skeletal concepts of leadership succession representation remains, it is very clear that no specific model is referred either through academia or real-world observation implementation, like the success accomplished by the private sector.

In contrast, Kur and Bunning (2002) found that 30 percent of the organizations that employed systematic development approaches towards leadership succession were able to avoid the development of leadership vacuums. To address the operational effectiveness imperative, a leadership succession program must ensure that there is a pool of candidates who understand the complexities of the daily operations and who are able to take over in the event that an unplanned succession event occurs.

Although the Malaysian Public Service had put in place training programs to ensure that their personnel received training, through the Pekeliling Perkhidmatan Bilangan 6, Tahun 2005; the Surat Pekeliling Perkhidmatan Bilangan 2, Tahun 2005; and the Pekeliling Perkhidmatan Bilangan 6, Tahun 2010; most of the training was not in the areas required for these personnel in equipping and preparing them to be the next generation of leaders or management. It was also found that in the pipeline for promotion, the top management had reservations on whom they would want to be promoted next, and this had turned into blockages to those who were already being prepped thus impeding the career path to these personnel who then became frustrated and opted either for a transfer or an early retirement.

In the Malaysian public service, there is a form of "punishment" that has been commonly used by JPA, especially those who are "reported" to have illnesses, underperformance, or even being deemed "not suitable" for the public service. They placed such personnel in JPA, to be observed under the Penempatan Khas, or "Special Placement" where these personnel will spend the remainder of their time in JPA being in "cold storage". The end result is that the level of loyalty, commitment and motivation is seen deteriorating, thus ultimately frustrates the ambitious, talented personnel to being in the pipelines for leadership succession, and impede their own career advancement. This has led to a further shrink towards the talent pool from which JPA may draft up for the public service leadership succession process.

Overall, most leadership succession programs assist in managing the organization's direction. Any succession event at the higher management level, planned or unplanned, tends to lead to changes in the composition of management found in the system (Wiersema, 1995), as well as the composition of the higher management committee (Ward et. al., 1999). Changes at this level have been shown to affect the implementation of the organization's strategic vision (Hambrick, Cho and Chen, 1996; Dooley and Fryxell, 1999) and the achievement of long-term performance goals (Virany, Tushman and Romanelli, 1992). To address the strategic direction requirement, a leadership succession program must ensure that candidates are available to lead the organization in the intended direction (Cannella and Shen, 2001; Shen and Cannella, 2002).

\section{Observations}

Definitively, leadership succession programs should be developed to assist in maintaining the confidence of stakeholders, as higher management succession events are often viewed by stakeholders as a signal of either good or poor management at the higher management committee level. Stakeholders tend to react positively to the ascension of the heir apparent to the higher management's position (Shen and Cannella, 2003) and to embark an initiated and smoothly executed successions (Sridharan and St John, 1998; 
Furtado and Rozeff, 1987; Freidman and Singh, 1989).

On the other hand, Shen and Cannella (2003) recorded negative stakeholder reactions when heirs apparent exited organizations. To address the stakeholder perception imperative, a leadership succession program must ensure smooth identification, preparation, retention and ultimately the installation of a new higher management personnel.

Despite the total lack of public sector literature on the subject, it is still important to highlight to the public sector how leadership succession planning should be addressed and proposing the ideal model for it to be implemented successfully may restore confidence in the Malaysian Public Service as well.

\section{Conclusion}

Leadership succession planning is a key element of an effective strategy for managing talent and ensuring that an organization achieves its future goals. As organizations lament another impending retirement crisis and leadership shortage, succession planning is once again coming to the fore in public sector human resource management.

While the private sector has increasingly focused on creating leadership succession planning programs that align with their challenging business needs, the Malaysian Public Service has lagged behind. This is largely due to the complexity of implementing these programs in the public sector. Challenges include the nature of tenure and political leadership in the public sector, personnel system rules, lack of resources and lack of focus. Literature on successful programs is scant but successful public sector models and approaches have been implemented at various levels by other countries' public service agency.

\section{References}

Barkdoll, G. and Mocniak, N. (1993). Strategically Managing the SES Crisis of 1994. The Public Manager. Vol. 22, No. 1

Burdett, J. (1993). Crafting Tomorrow's Leadership Today: A Practitioner's View of

Succession and Replacement Planning. International Journal of Manpower.

Vol. 14,No. 8

Cannella, A., \& Shen, W. (2001). So close and yet so far: Promotion versus exit for CEO heirs apparent. Academy of Management Journal, Vol. 44, No. 2

Cipolla, F. (1993). Federal Executive Turnover: Crisis or Opportunity. The Public Manager. Vol. 22, No. 1

Dooley, R. and Fryxell, G. (1999). Attaining Decision Quality and Commitment From Dissent: The Moderating Effects of Loyalty and Competence in Strategic Decision-Making Teams. Academy of Management Journal. Vol. 42

Friedman, S. and Singh, H. (1989). CEO succession and stockholder reaction: The influence of organizational context and event content. Academy of Management Journal, Vol. 32

Furtado, E. and Rozeff, M. (1987) The Wealth Effects of Company Initiated Management Changes. Journal of Financial Economics, Vol. 18

Gilmore, T. (1988). Making a Leadership Change: How Organizations and Leaders Can Handle Leadership Transitions Successfully. San Francisco: Jossey-Bass Publishers

Hambrick, D., Cho, T. and Chen, Ming-Jer. (1996). The Influence of Top Management Team Heterogeneity on 
Firms' Competitive Moves. Administrative Science Quarterly. Vol.41

Hirsh, W. (2002). Succession Planning Demystified. Institute for Employment Studies (IES). Report No. 372

Jabatan Perkhidmatan Awam (2005). Pekeliling Perkhidmatan Bilangan 6, Tahun 2005 translated: Service Circular Number 6, Year 2005)

Jabatan Perkhidmatan Awam (2005). Surat Pekeliling Perkhidmatan Bilangan 2, Tahun 2005 (translated: Service Circular Letter Number 2, Year 2005)

Jabatan Perkhidmatan Awam. (2006). Pekeliling Perkhidmatan Bilangan 3, Tahun 2006 (translated: Service Circular Number 3, Year 2006)

Jabatan Perkhidmatan Awam. (2010). Pekeliling Perkhidmatan Bilangan 6, Tahun 2010 (translated: Service Circular Number 6, Year 2010)

Jabatan Perkhidmatan Awam (2014). Kerangka Transformasi Perkhidmatan Awam (translated: Public Service Transformation Framework)

Kesner, I. and Sebora, T. (1994). Executive Succession: Past, Present and Future. Journal of Management. Vol. 20, No. 2

Kur, E. and Bunning, R. (2002). Assuring corporate leadership for the future. Journal of Management Development, Vol. 21, No. 9

Rothwell, W. (2005). Effective Succession Planning, $3^{\text {rd }}$ Edition. AMACOM

Santora, J.C., and Sarros, J.C. (1995). Mortality and leadership succession: A case study.
Leadership and Organization Development Journal, Vol. 16, No. 7

Schall, E. (1997). Public-Sector Succession: A Strategic Approach to Sustaining Innovation. Public Administration Review, 57(1), 410.

Shen, W. and Cannella, A. (2002). Revisiting the Performance Consequences of CEO Succession: The Impacts of Successor Type, Postsuccession Senior Executive Turnover, and Departing CEO Tenure. The Academy of Management Journal, Vol. 45, No. 4

Shen, W. and Cannella, A. (2003). Will succession planning increase shareholder wealth? Evidence from investor reactions to relay CEO successions. Strategic Management Journal, Vol. 24, No. 2

Sridharan, U., \& St John, C. (1998). The effects of organizational stability and leadership structures on firm performance. Journal of Managerial Issues, Vol. 10, No. 4

Virany, B., Tushman, M. and Romanelli, E. (1992). Executive succession and organization outcomes in turbulent environments: An organization learning approach. Organizational Science, Vol. 3

Ward, T., Smith, S. and Finke, R. (1999). Creative cognition. In R. J. Sternberg (Ed.), Handbook of creativity. New York: Cambridge University Press.

Wiersema, F. and Treachy, M. (1995). The discipline of market leaders: Choose your customers, narrow your focus, dominate your market. London: HarperCollins. 